\title{
ADVANCEMENT AND SETBACK IN ISLAMIC BANKING PRODUCTIVITY IN ASEAN: DO TECHNOLOGICAL CHANGES MATTER?
}

\author{
Aam Slamet Rusydiana ${ }^{1}$ and Aisyah Assalafiyah ${ }^{2}$ \\ ${ }^{1}$ Sharia Economic Applied Research \& Training (SMART), Indonesia, aamsmart@gmail.com \\ ${ }^{2}$ Sharia Economic Applied Research \& Training (SMART), Indonesia, assalafiyahsmart@gmail.com
}

\begin{abstract}
This study applies Data Envelopment Analysis (DEA) to measure the efficiency level of 24 Islamic banks in four ASEAN countries (Indonesia, Malaysia, Brunei Darussalam and Thailand) over the 2010-2019 period. Specifically, this study uses the Banker, Charnes and Cooper (BCC) model as a basic approach in DEA with variable return to scale assumption. The Malmquist index was also employed to explain whether the changes in Islamic banks' efficiency and productivity is affected by the efficiency changes or technological changes. According to the Malmquist index scores on total factor productivity (TFP) change, 17 of the 24 Islamic banks (or 70.8 percent) achieved an improvement in productivity over the research period, with Thailand recording the highest productivity level increase. Overall, the most productive Islamic bank was Affin Islamic Bank Berhad. Finally, it was observed that there was a productivity growth in the last two years of the period, namely 2017-2018 and 2018-2019. The productivity change was driven more by efficiency than by technology, implying that Islamic banks in ASEAN countries must improve the technological aspect.
\end{abstract}

Keywords: Productivity, Islamic banks, ASEAN.

JEL classification: C14; D24; F65; G21.

\section{Article history:}

Received : October 8, 2020

Revised : January 14, 2021

Accepted : : May 27, 2021

Available online : August 31, 2021

https://doi.org/10.21098/jimf.v7i3.1322 


\section{INTRODUCTION}

\subsection{Background}

The global financial crisis of 2007-2008 prompted many to search for a more resilient banking system. In this regard, the Islamic financial system, with its fast-growing Islamic banking segment, has emerged as a viable alternative for improving national banking systems (Johnes, Izzeldin, Pappas, \& Alexakis, 2019). The Islamic banking sector recorded an annual asset growth of 14\% in 2019, rising from USD 1,745 billion in 2018 to 1,993 billion in 2019 (Refinitiv \& Islamic Corporation for the Development of the Private Sector, 2020). In many countries and regions, including Malaysia and the Middle East, Islamic banking has become systemically more important, with a market share of more than $15 \%$. Its penetration into other countries, including non-Muslim ones, has also been rapid, which signifies the recognition of Islamic banking worldwide (Rahim, Rahman, \& Rosman, 2013).

Given the well-accepted role of banking in economic development, and the recent fast growth of Islamic banking, an assessment of the productivity of Islamic banking in its intermediary function is needed. Although there is a wide range of literature on Islamic banking productivity, which encompasses many countries that have adopted it, there are few studies on Islamic banking productivity in the Association of Southeast Asian Nations (ASEAN) (Kamarudin, Hue, Sufian, \& Mohamad Anwar, 2017). The region has witnessed th increasing importance of Islamic banking (Omar, Abd. Majid, \& Rulindo, 2007), and with the progress of the economic integration of the ASEAN Economic Community (AEC), Islamic banks are expected to play greater roles. This means that they have to be ready and have a sufficient level of production to meet the challenges of integration.

This study examines the productivity of Islamic banking in four countries in ASEAN, namely Indonesia, Malaysia, Brunei Darussalam, and Thailand, using the Malmquist Productivity Index (MPI). In the literature, several studies have examined the productivity of Islamic banking using this index, including, among others, Jubilee, Kamarudin, Latiff, Hussain, \& Tan (2021) and Nugrohowati, Fakhrunnas, and Haron (2020). Jubilee et al. (2021) assess the differences between Islamic and conventional bank productivity in the context of the Middle East, Southeast Asia and South Asia regions, based on a sample of 385 banks from 18 countries over the period 2008-2017. In addition, Nugrohowati et al. (2020) employed Malmquist index analysis to assess Islamic banking performance in the ASEAN region over the period 2015 - 2018. This study differs from the previous research in various aspects. First, it develops the Malmquist index method based on data envelopment analysis (DEA). Second, it specifically focuses on four ASEAN countries. Finally, the data employed span a longer and more recent period, the ten years from 2010 and 2019, covering one business cycle period (Yan \& Huang, 2020; Adarov, 2021; Kim, 2021).

\subsection{Objective}

The paper evaluates productivity changes in ASEAN Islamic banking using the Malmquist productivity index (MPI). This index is a feature of the DEA technique and evaluates productivity within companies to assess changes in efficiency and technology using a set of established inputs and outputs. The Malmquist index can also be used to examine how performance varies over time. 
The remainder of the paper is organised as follows. The second section explores the general background and analyses previous research, while the third section describes the methodology. The fourth section presents and discusses ASEAN Islamic bank productivity, providing an analysis of the most productive years, Islamic banks and countries. The fifth section concludes the paper, with a summary of the main discussion, together with recommendations.

\section{LITERATURE REVIEW}

\subsection{Overview}

Considerable attention has been devoted to measurement of the efficiency and productivity of financial institutions. Islamic banking is no exception, and has received growing interest since the 2007/2008 global financial crisis (Otaviya \& Rani, 2020) due to its resiliency during that period. Islamic banking differs from conventional banking in that prohibits usury (interest) and gharar (uncertainty) and emphasises justice and transparency. Apart from its intermediation services, Islamic banking also offers fee-based services and other products which is in accordance with Shari'ah, such as profit and loss sharing financing product, so it is expected to play a positive role in economic growth and stability.

There are presently over 300 Islamic banks located in many countries. These banks are expected to develop further in the locations where they operate in order to fulfil current and future Muslim needs. Moreover, the size of the Muslim population continues to increase every year in various countries and followers' awareness of the importance of choosing products that are in accordance with Islamic law, including financial products, has further expanded the opportunities for the development of Islamic banks. It is estimated that the Muslim population will reach 2.3 billion by 2030, hence providing a sizable opportunity for the future growth of Islamic banking (Otaviya \& Rani, 2020).

In Asia, the Muslim population makes up 60 per cent of the total number of Muslims globally, with Indonesia having the largest population of around 250 million. Currently, Malaysia is the leading Islamic financial market, valued at more than USD 412 billion, and the market share of Islamic financial assets reached $40 \%$ in 2020. These Muslim populations are likely to become the future primary market for Islamic finance (Andriyani, Usman, \& Pambuko, 2020).

Islamic banking is highly developed in several Muslim-majority countries, including Indonesia, Malaysia, and Brunei Darussalam (Rani, Sukmaningrum, \& Salleh, 2020). According to the Islamic Finance Development Report of 2019, the Islamic finance industry's assets increased by 3\% in 2018 to \$2.5 trillion, from \$2.4 trillion in 2017. This growth was lower than in past years, and was particularly evident in several of the industry's major markets, where the wider economy has been stagnant.

The Islamic financial market in Asia, particularly in ASEAN, is likely to experience significant developments (Rani et al., 2020). At the same time, it is expected that banking competition will become stronger. This means that Islamic banks must to be more efficient in order for them to survive in the increasingly competitive market. Hence, there is an urgent need to measure the level of efficiency of all Islamic banks, especially in ASEAN, so that the next steps in their development can be proposed. Analysis of the level of banking efficiency can 
help Islamic banking managers to determine appropriate strategies for efficiency improvement. As for the government or regulators, the results can be used to formulate policies to encourage the development of the Islamic banking industry (Solihin, Achsani, \& Saptono, 2016).

The ASEAN Economic Community (AEC) was realised in 2015, a difficult period for Islamic banking in Indonesia. The AEC, with the ASEAN Banking Integration Framework (ABIF), has the potential to shape the competitiveness of Indonesia's banking sector through greater penetration and more participation of foreign banks in the Indonesian markets. At the same time, it might provide a chance for Islamic banks in ASEAN nations, to expand if they are efficient (Hadad et al., 2011).

According to the 2019 Global Islamic Finance Report's Islamic Finance Country Index, Indonesia and Malaysia are the top two countries in Islamic finance, with scores of 81.93 and 81.05 respectively. Another country in ASEAN, Brunei Darussalam, is listed sixth, with the score of 49 . The findings of the GIFR index evaluation make Indonesia in particular a benchmark for establishing the Islamic financial sector in other nations, and ASEAN in general, which is a centre of the growth of the international Islamic finance industry (Sufian, 2010).

The fast expansion of the Islamic finance industry has made Southeast Asia an important centre of global Islamic finance, with each ASEAN nation having its own peculiarities in the development of Islamic banking. Malaysia is the ASEAN country with the fastest expanding Islamic banking development. Indonesia is also actively involved in the development of Islamic banking (Usman, Andriyani, \& Pambuko, 2019), although its development is slower than that of Malaysia. In addition to these two nations, Brunei Darussalam is rapidly expanding its Islamic banking system. Furthermore, Singapore, the Philippines, and Thailand are also eager to expand this sector.

\subsection{Previous Studies}

Various studies have been conducted on assessing the efficiency and productivity of Islamic banking, most of which focus on one particular country, although others have discussed the issue from a broader perspective and on a cross-country basis.

One example is the research by Rahim et al. (2013), which found that Islamic banks must have a high level of efficiency to withstand competitive pressures and financial crises that may occur in the future. They indicate that the primary source of technical inefficiency among Islamic banks is their scale of operations. In general, Islamic banks achieve high scores for pure technical efficiency, which indicates that bank management can efficiently control costs and use imports to maximise output, regardless of the scale effect. The results of their study showed that the average scores of Islamic banks in Asian countries meant they were relatively more efficient than banks in MENA countries.

Furthermore, research by Yulita and Rizal (2016) aimed to measure the efficiency level of Islamic banking in Malaysia and Indonesia using a comparative method and to analyse the factors that affect the efficiency level of Islamic banking in the two countries. The results of their study indicate that the level of efficiency of Islamic banking in Malaysia and Indonesia fluctuates, and that in Indonesia it 
is more efficient than in Malaysia. The causes of inefficiency include the level of deposits, total financing, fixed assets, and personnel costs.

Research conducted by Solihin et al. (2016) on Islamic banking and economic integration in ASEAN found that Brunei Darussalam, the Philippines and Singapore each only had one Islamic bank. However, the DEA data processing results show that each of the banks in the three countries is efficient, but that none of them is not a threat to Islamic banking in other ASEAN countries. Furthermore, it was also found that out of the five ASEAN countries that have registered Islamic banks, Islamic banking competition only occurs in Indonesia and Malaysia. The other three countries, namely Brunei Darussalam, Singapore, and the Philippines, do not have sufficiently strong Islamic banks to compete, even though they are efficient.

Islamic banks in Indonesia will be more efficient if they can reduce their operational costs. The average level of DMU efficiency in the country using the intermediation approach is below the ASEAN average. In contrast, the average level of DMU efficiency in Malaysia is above the average. This condition shows that Islamic banks in Malaysia are more efficient than ones in Indonesia. However, if the operational costs, including human resources and other operational costs, are excluded from the input variable, the efficiency of Islamic banks in Indonesia is above the average for ASEAN and Malaysia.

Finally, among the studies conducted to assess the performance of Islamic banking in ASEAN, Wanke, Hassan, \& Gavião (2017) found that the critical role of Islamic principles in banking efficiency, and the low efficiency of Islamic banking, were influenced by culture and regulatory barriers, especially in foreign private Islamic banks. They suggest that the government and regulators develop action plans to help foreign private Islamic banks improve their efficiency, in line with the different characteristics of individual banks.

Based on the studies reviewed above, it can be concluded that several have aimed to assess the level of efficiency and productivity of Islamic banking in certain countries. Many have also evaluated the causes of the inefficiency of Islamic banking, in order for these to become a reference for Islamic banking practitioners to improve their performance.

This comprehensive research was conducted specifically in the ASEAN region and involved four countries. The ASEAN region is attractive as the object of research, given its great opportunity to support the ASEAN Economic Community (AEC) programme, which aims to support Southeast Asia in becoming a more globally competitive country, with free trade and direct competition between countries, including in the field of Islamic banking.

Therefore, there is a need for research to measure the level of productivity and efficiency of banks in ASEAN over one business cycle (Yan \& Huang, 2020; Adarov, 2021; Kim, 2021). That is the reason why this research was conducted, in an effort to test comparative productivity between Islamic banks in ASEAN countries by using complete data for each input of output for the ten years of the study period. In addition, the study also examines the level of efficiency of banking in ASEAN by combining the results of the data envelopment analysis research with the Malmquist productivity index to produce stronger data. 


\section{METHODOLOGY}

\subsection{Data}

This study employs a sample of Islamic banks operating in four ASEAN countries over the period 2010-2019. All the relevant data were compiled from the banks' annual reports, available on their official websites. For conformity, the figures obtained from their respective reports were converted into US dollars. In selecting the sample banks, it was required that all the relevant data were available over the span of ten years from 2010 to 2019, resulting in a panel sample of 24 Islamic banks.

The data used to analyse efficiency and productivity included personnel costs, administrative expenses, deposits, financing and operating income. Adopting the intermediation approach to measuring bank productivity, the first three sets of data were taken as inputs and the last two as outputs.

\subsection{Model Development}

Data envelopment analysis (DEA) was initially developed by Charnes, Cooper \& Rhodes (1978) and later extended by Banker, Charnes, \& Cooper (1984) to measure the productivity and efficiency of business units. It allows for multiple (weighted) outputs and multiple (weighted) inputs in measuring productivity or efficiency, normally referred to as the level of weighted output produced from given inputs. In the efficiency literature, DEA is widely used to measure technical efficiency, including the efficiency of financial institutions (Sharma et al., 2013).

A business unit is efficient if it can produce maximum output for a given level of inputs, or if it can minimise costs for a given level of output. Ozcan (2008) divides efficiency into several aspects: technical efficiency, scale efficiency, cost efficiency, and allocation efficiency. The process of turning inputs into outputs is known as technical efficiency. Because this notion only relates to internal technical connections between inputs and outputs, a firm is regarded to be economically effective if it can reduce production costs to generate a given output, while remaining within standard technology and market price levels.

In this paper, the productivity of Islamic banks is calculated using the approach developed by Banker, Charnes, \& Cooper (henceforth, BCC), which is based on the assumption of variable return to scale (VRS). This VRS assumption allows the change in output to be disproportionate to the increase in input, depending on whether a business unit has increasing or decreasing return to scale.

The intermediation approach is adopted to reflect the activities of Islamic banks. The selection of input-output variables is in line with Sufian (2007), Ascarya and Yumanita (2008) and Rusydiana and Marlina (2019). Table 1 presents the input and output variables used, together with their descriptive statistics. The analytical tool used to measure the Malmquist productivity index was DEAP 2.1 software. 
Table 1.

Descriptive Statistics of Input-Output Variables

\begin{tabular}{lccccc}
\hline \multirow{2}{*}{ Indicator } & \multicolumn{2}{c}{ Output (USD thousand) } & \multicolumn{3}{c}{ Input (USD thousand) } \\
\cline { 2 - 6 } & Financing & $\begin{array}{c}\text { Operating } \\
\text { Income }\end{array}$ & $\begin{array}{c}\text { Personnel } \\
\text { Cost }\end{array}$ & Adm. Cost & Deposits \\
\hline Mean & $3,506,284$ & 257,015 & 19,988 & 56,968 & $4,517,850$ \\
Max & $45,501,271$ & $2,709,261$ & 142,183 & 448,247 & $52,896,405$ \\
Min & 1,910 & 511 & 572 & 111 & 11,217 \\
Std.Dev & 6339728 & 364234 & 24038 & 71887 & 7389526 \\
\hline
\end{tabular}

Source: Author (2020)

In 1982, Caves, Christensen, and Diewert (CCD) first proposed the DEA-based Malmquist productivity index (MPI) approach, which Färe, Grosskopf, Lindgren, and Roos (1992) and Färe, Grosskopf, Norris, and Zhang (1994) then empirically applied. Non-parametric (Malmquist) and parametric (Fischer and Tornqvist) indices differ in their behavioural assumptions and detect random mistakes in data, often known as noise. The advantage of using MPI indices over others is that they do not require pricing data and also remove the requirement for assumptions about the technological structure.

In this study, banks' productivity changes are measured using the outputoriented MPI; the change in total factor productivity change (TFPCH) is assigned to technological change (TECHCH) and efficiency change (EC) (EFFCH). According to Färe et al. (1994), the efficiency change index can be further decomposed into its mutually comprehensive PECH (pure efficiency change) components, calculated relative to the VRS technology and a component of SECH (scale changes) capturing changes in the deviation between VRS and CRS technologies. The decomposition of TFPCH is shown in Figure 1.

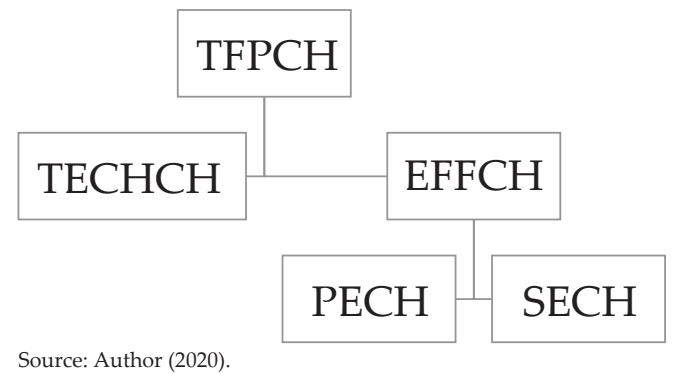

Figure 1.

Productivity Indices

The efficiency scores must range between zero and one. The radial distance from the projected production border to the DMUs under consideration is reflected in the efficiency score (Kamarudin et al., 2017). 


\subsection{Method}

The first-generation productivity index was developed by Caves et al. (1982). There are two Malmquist productivity indices, namely the Malmquist input quantity index and Malmquist output quantity index. The former is used for a production unit, at observation times $t$ and $t+1$, for reference technology in the period $k, k=$ $t$ and $t+1$, and measures the change in the observed input quantity between time $\mathrm{t}$ and $\mathrm{t}+1$, where:

$$
M I_{k}\left(y_{k}, x_{t}, x_{t+1}\right)=\frac{E_{k}^{I}\left(y_{k}, x_{t}\right)}{E_{k}^{I}\left(y_{k}, x_{t+1}\right)}, k=t, t+1
$$

The output index is used for a production unit, at observation times $t$ and $t+1$, for reference technology in the period $k, k=t$ and $t+1$. It only measures the change in the quantity of the output observed between times $t$ and $t+1$, where:

$$
M O_{k}\left(y_{t}, y_{t+1}, x_{k}\right)=\frac{E_{k}^{O}\left(y_{t+1}, x_{k}\right)}{E_{k}^{O}\left(y_{t}, x_{k}\right)}, k=t, t+1
$$

Bjurek (1996) introduced a new definition of the Malmquist productivity index for production units between $t$ and $t+1$ based on the level of technology at times $k$, $k=t$, and $k=t+1$, following the tradition of most productivity indices. The index built was a ratio between an output index and an input index, according to the Tornqvist productivity index, where:

$$
\operatorname{MTFP}_{k}=\frac{M O_{k}\left(y_{t}, y_{t+1}, x_{k}\right)}{M I_{k}\left(y_{k}, x_{t}, x_{t+1}\right)}=\frac{E_{k}^{O}\left(y_{t+1}, x_{k}\right) / E_{k}^{O}\left(y_{t}, x_{k}\right)}{E_{k}^{I}\left(y_{k}, x_{t}\right) / E_{k}^{I}\left(y_{k}, x_{t+1}\right)}, k=t, t+1
$$

The equation above expresses the relationship between the output index and the Malmquist input index. Productivity has grown if the productivity index value is greater than one. However, if the index value is less than one, the level of production has fallen. If it equals 1 , the productivity level remains constant.

The Cobb-Douglas theory is used in this study to estimate TFP growth and its components, based on the Malmquist index. The Cobb-Douglas production function is as follows:

$$
Y=A * L^{a} * K^{(1-a)}
$$

The equation is written as a measure of total factor productivity, for which scalar A has economic value, since it is the geometric weighted average of the inputs utilised to generate the real output. As a result, A may be defined as actual output per unit of input. This is a measure of productivity that is better than $\mathrm{Y} / \mathrm{L}$ or $\mathrm{Y} / \mathrm{K}$, which are partial productivity measures that do not consider the possibility of the number of other inputs used. The Malmquist productivity index, an extension of data envelopment analysis, was employed to assess efficiency in this study. 
The productivity change factor can be seen through the values of the efficiency change index $(\mathrm{EFFCH})$ and the technology change index (TECHCH) to explain the reasons for changes in productivity. In addition, the pure efficiency change index $(\mathrm{PECH})$ and scale efficiency change Index $(\mathrm{SECH})$ were used to determine the cause of the change in the efficiency change index (EFFCH). The value of total factor productivity (TFP) shows the change in the index. A value of $M>1$ indicates an increase in productivity; $M=1$ indicates no increase in productivity; and $M<1$ indicates a fall.

\section{RESULTS AND ANALYSIS}

\subsection{Results}

This section discusses the efficiency level of 24 Islamic ASEAN banks during the period 2010 to 2019 using the data envelopment analysis (DEA) method. The efficiency scores by bank and year are presented in Table 2. 


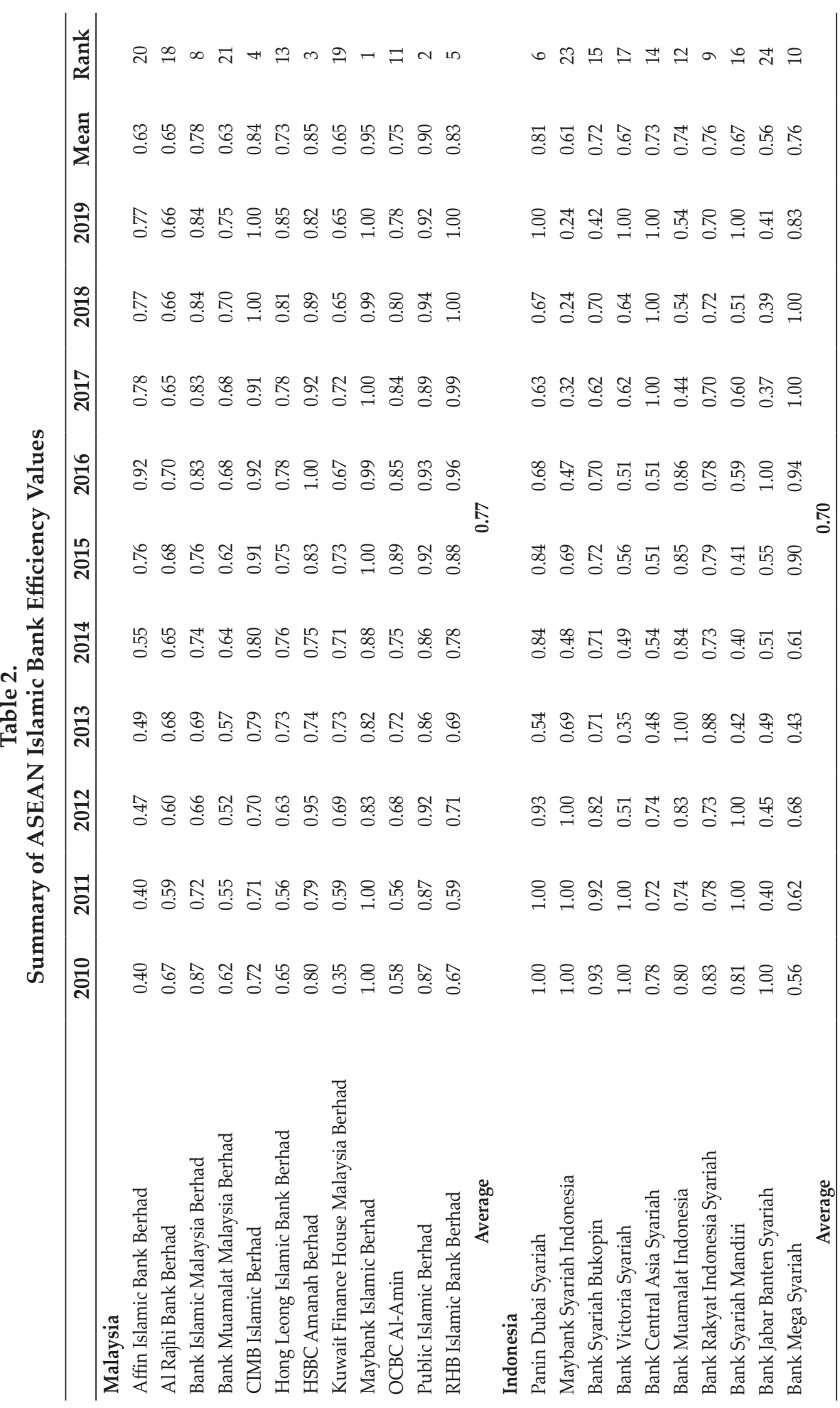




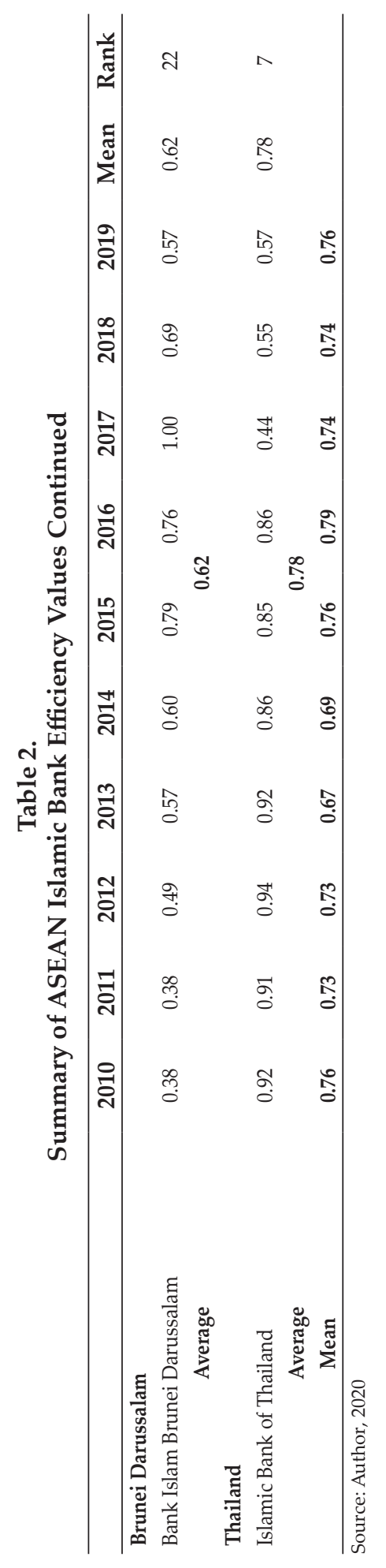


Based on Table 2, it can be seen that the efficiency value of Islamic banking in ASEAN fluctuates over the years. The average efficiency score of the 24 banks in the sample over the 10-year period is 0.73 , with several of the banks achieving maximum values in several different years. In 2019, Bank Victoria Syariah, Bank Central Asia Syariah, Bank Syariah Mandiri, CIMB Islamic Berhad, Maybank Islamic Berhad, Panin Dubai Syariah and RHB Islamic Bank Berhad reached the maximum efficiency level. The result shows that four of these banks are from Indonesia and three from Malaysia.

In general, if we calculate the overall average of the 24 Islamic banks over the 10 year period, we find that the top five most efficient banks are (i) Maybank Islamic Berhad, with a mean of 0.95; (ii) Public Islamic Berhad, with a mean of 0.90; (iii) HSBC Amanah Berhad, with a mean of 0.85; (iv) CIMB Islamic Berhad, with a mean of 0.84; and (v) RHB Islamic Bank Berhad, with a mean of 0.83. All these banks are domiciled in Malaysia. On the other hand, the five least efficent Islamic banks were Affin Islamic Bank Berhad, Bank Muamalat Malaysia Berhad, Bank Islam Brunei Darussalam, Maybank Syariah Indonesia and Bank Jabar Banten Syariah, which recorded average efficiency scores below 0.65. Bank Jabar Banten Syariah had the lowest score, with an average efficiency value of 0.56 . Table 2 shows that the efficiency of Islamic banking in ASEAN, although not reaching the maximum value, has reached a medium level, as indicated by the lowest value obtained by Bank BJB Syariah still being above 0.5.

The calculation then continued with a productivity assessment using the MPI or Malmquist Productivity Index method. Table 3 shows the estimated MPI results for Islamic banking in the four ASEAN countries.

Table 3.

Malmquist Index Summary Based on Annual Averages

\begin{tabular}{cccccc}
\hline Year & EFFCH & TECH & PECH & SECH & TFPCH \\
\hline $2010-2011$ & 1.352 & 0.646 & 1.061 & 1.274 & 0.873 \\
$2011-2012$ & 0.679 & 1.480 & 1.026 & 0.662 & 1.005 \\
$2012-2013$ & 1.496 & 0.606 & 1.035 & 1.445 & 0.907 \\
$2013-2014$ & 0.599 & 1.625 & 0.737 & 0.813 & 0.974 \\
$2014-2015$ & 1.226 & 0.746 & 1.040 & 1.179 & 0.915 \\
$2015-2016$ & 1.366 & 1.010 & 1.327 & 1.029 & 1.379 \\
$2016-2017$ & 0.884 & 0.942 & 0.963 & 0.918 & 0.833 \\
$2017-2018$ & 1.223 & 1.355 & 1.102 & 1.109 & 1.657 \\
$2018-2019$ & 0.814 & 1.267 & 0.828 & 0.984 & 1.032 \\
Mean & 1.022 & 1.015 & 1.001 & 1.021 & 1.038 \\
\hline
\end{tabular}

Source: Author (2020)

Table 3 indicates that there was an increase in productivity growth in 20172018, indicated by the TFPCH value 1.657 and decrease in 2018-2019 with TFPCH value 1.032. However, a small increase in TFPCH indicates a lower PECH value of 1.001. This means that the increase in the productivity of ASEAN Islamic banks has been contributed to by the high level of innovation or efficiency (EFFCH) of 1.022, while the value of TECH (i.e. 1.015) is lower than that of EFFCH. 
The study also calculates the MPI for each Islamic ASEAN bank over the 20102019 period; the results can be seen in Table 4.

Table 4.

Malmquist Index Summary Based on Islamic Banks

\begin{tabular}{lccccc}
\hline DMU & EFFCH & TECH & PECH & SECH & TFPCH \\
\hline CIMB Islamic Bank Berhad & 0.806 & 1.021 & 0.898 & 0.897 & 0.822 \\
Hong Leong Islamic Bank Berhad & 1.343 & 0.902 & 1.268 & 1.059 & 1.212 \\
Bank Islamic Malaysia Berhad & 0.873 & 0.924 & 0.985 & 0.887 & 0.807 \\
Al Rajhi Bank Berhad & 1.263 & 0.876 & 1.190 & 1.062 & 1.107 \\
HSBC Amanah Berhad & 0.951 & 1.013 & 0.804 & 1.183 & 0.964 \\
Kuwait Finance House Malaysia Berhad & 1.196 & 0.943 & 1.050 & 1.139 & 1.129 \\
Maybank Islamic Berhad & 0.886 & 0.779 & 1.000 & 0.886 & 0.690 \\
OCBC Al-Amin & 1.030 & 1.026 & 1.015 & 1.015 & 1.056 \\
Public Islamic Berhad & 0.962 & 1.030 & 0.955 & 1.007 & 0.991 \\
RHB Islamic Bank Berhad & 0.873 & 1.029 & 0.846 & 1.031 & 0.899 \\
Affin Islamic Bank Berhad & 1.000 & 1.487 & 1.000 & 1.000 & 1.487 \\
Bank Muamalat Malaysia Berhad & 1.041 & 0.997 & 0.985 & 1.057 & 1.038 \\
Bank Bank Jabar Banten Syariah & 1.090 & 1.117 & 1.078 & 1.012 & 1.217 \\
Bank Syariah Bukopin & 1.000 & 1.028 & 1.000 & 1.000 & 1.028 \\
Bank Central Asia Syariah & 0.971 & 1.095 & 0.975 & 0.996 & 1.064 \\
Bank Victoria Syariah & 1.000 & 1.101 & 1.000 & 1.000 & 1.101 \\
Maybank Syariah Indonesia & 1.000 & 1.011 & 1.000 & 1.000 & 1.011 \\
Panin Dubai Syariah & 1.140 & 1.235 & 1.137 & 1.003 & 1.409 \\
Bank Muamalat Indonesia & 1.307 & 0.939 & 1.176 & 1.112 & 1.227 \\
Bank Syariah Mandiri & 0.988 & 1.089 & 0.956 & 1.034 & 1.077 \\
Bank Rakyat Indonesia Syariah & 0.960 & 0.775 & 0.974 & 0.985 & 0.744 \\
Bank Mega Syariah & 0.903 & 1.117 & 0.909 & 0.993 & 1.009 \\
Bank Islam Brunei Darussalam & 1.064 & 0.989 & 0.938 & 1.133 & 1.052 \\
Islamic Bank of Thailand & 1.075 & 1.068 & 1.007 & 1.068 & 1.148 \\
& 1.022 & 1.015 & 1.001 & 1.021 & 1.038 \\
\hline \multicolumn{1}{c}{ Mean } & & & & &
\end{tabular}

Source: Author, 2020

Based on Table 4, the highest productivity level was achieved by Affin Islamic Bank Berhad, with a TFPCH value of 1.487. One of the factors affecting its high level of productivity was technological innovation (TECH), also with a value of 1.487. On the other hand, efficiency change $(\mathrm{EFFCH})$ at the bank tended to be stagnant, at 1.000. In addition, there are also other Islamic banks with low productivity values compared to those sampled. For example, Maybank Islamic Berhad has a low productivity rate (TFPCH) of 0.690 , and a low level of technological innovation, at 0.779 . 
On the other hand, the level of efficiency change at Maybank Islamic Berhad is still relatively high, at 0.886 . One of the factors causing the decline in the level of productivity at the bank is the low level of technological innovation; the level of productivity of Islamic banks in ASEAN as a whole has increased.

The research also calculated MPI using a sample of banks for a given country. The results can be seen in Table 5 .

Table 5.

Malmquist Index Summary Based on Country

\begin{tabular}{|c|c|c|c|c|c|}
\hline DMU & EFFCH & TECH & PECH & SECH & TFPCH \\
\hline \multicolumn{6}{|l|}{ Malaysia } \\
\hline CIMB Islamic Bank Berhad & 0.806 & 1.021 & 0.898 & 0.897 & 0.822 \\
\hline Hong Leong Islamic Bank Berhad & 1.343 & 0.902 & 1.268 & 1.059 & 1.212 \\
\hline Bank Islamic Malaysia Berhad & 0.873 & 0.924 & 0.985 & 0.887 & 0.807 \\
\hline Al Rajhi Bank Berhad & 1.263 & 0.876 & 1.190 & 1.062 & 1.107 \\
\hline HSBC Amanah Berhad & 0.951 & 1.013 & 0.804 & 1.183 & 0.964 \\
\hline Kuwait Finance House Malaysia Berhad & 1.196 & 0.943 & 1.050 & 1.139 & 1.129 \\
\hline Maybank Islamic Berhad & 0.886 & 0.779 & 1.000 & 0.886 & 0.69 \\
\hline OCBC Al-Amin & 1.030 & 1.026 & 1.015 & 1.015 & 1.056 \\
\hline Public Islamic Berhad & 0.962 & 1.030 & 0.955 & 1.007 & 0.991 \\
\hline RHB Islamic Bank Berhad & 0.873 & 1.029 & 0.846 & 1.031 & 0.899 \\
\hline Affin Islamic Bank Berhad & 1.000 & 1.487 & 1.000 & 1.000 & 1.487 \\
\hline Bank Muamalat Malaysia Berhad & 1.041 & 0.997 & 0.985 & 1.057 & 1.038 \\
\hline Average & 1.019 & 1.002 & 1.000 & 1.019 & 1.017 \\
\hline \multicolumn{6}{|l|}{ Indonesia } \\
\hline Bank Jabar Banten Syariah & 1.090 & 1.117 & 1.078 & 1.012 & 1.217 \\
\hline Bank Syariah Bukopin & 1.000 & 1.028 & 1.000 & 1.000 & 1.028 \\
\hline Bank Central Asia Syariah & 0.971 & 1.095 & 0.975 & 0.996 & 1.064 \\
\hline Bank Victoria Syariah & 1.000 & 1.101 & 1.000 & 1.000 & 1.101 \\
\hline Maybank Syariah Indonesia & 1.000 & 1.011 & 1.000 & 1.000 & 1.011 \\
\hline Panin Dubai Syariah & 1.140 & 1.235 & 1.137 & 1.003 & 1.409 \\
\hline Bank Muamalat Indonesia & 1.307 & 0.939 & 1.176 & 1.112 & 1.227 \\
\hline Bank Syariah Mandiri & 0.988 & 1.089 & 0.956 & 1.034 & 1.077 \\
\hline Bank Rakyat Indonesia Syariah & 0.960 & 0.775 & 0.974 & 0.985 & 0.744 \\
\hline Bank Mega Syariah & 0.903 & 1.117 & 0.909 & 0.993 & 1.009 \\
\hline Average & 1.036 & 1.051 & 1.021 & 1.014 & 1.089 \\
\hline \multicolumn{6}{|l|}{ Brunei Darussalam } \\
\hline Bank Islam Brunei Darussalam & 1.064 & 0.989 & 0.938 & 1.133 & 1.052 \\
\hline Average & 1.064 & 0.989 & 0.938 & 1.133 & 1.052 \\
\hline \multicolumn{6}{|l|}{ Thailand } \\
\hline Islamic Bank of Thailand & 1.075 & 1.068 & 1.007 & 1.068 & 1.148 \\
\hline Average & 1.075 & 1.068 & 1.007 & 1.068 & 1.148 \\
\hline
\end{tabular}

Source: Author (2020) 
As shown in Table 5, an increase in productivity growth has been experienced by the groups of Islamic banks in ASEAN countries. The highest increase occurred in the Islamic bank in Thailand, namely the Islamic Bank of Thailand, with a TFPCH of 1.148. This means that the total factor productivity of the Islamic Bank of Thailand has increased by $14.8 \%$. The factor that affected the high level of productivity of the bank was the high level of efficiency change (EFFCH) achieved, at 1.075 .

On average, Indonesia and Brunei Darussalam also saw an increase in the productivity of their Islamic banks, which recorded TFPCH values of 1.089 and 1.052 respectively. A supporting factor for the high level of productivity of Islamic banks in Indonesia was the high level of technological innovation (TECH), at 1.051. With regard to Islamic banking in Brunei Darussalam, its high level of productivity was down to the high level of efficiency change (EFFCH), at 1.064.

This study also divides all ASEAN Islamic banking into several quadrant categories based on MPI productivity scores and DEA efficiency scores. This quadrant analysis was developed from Kumar (2008). The average value of all productivity and efficiency values is calculated, where the average productivity value is 1.054 and the average efficiency value is 0.734 . These two averages are then used as a measure of Islamic banking which is the object of this research. If their score is more than average, then they are included in the categories of banks with high productivity and banks with high efficiency. Furthermore, the quadrant is determined by the two results, where if the bank is included in the category of high productivity and efficiency, then it is included in quadrant I. If the productivity is high and efficiency is low, then it is included in quadrant II. If productivity is low and efficiency is high, then it is included in quadrant III. Finally, if productivity and efficiency are low then it is included in quadrant IV.

Table 6.

ASEAN Islamic Banks Quadrant Category

\begin{tabular}{lccc}
\hline DMU & MPI & DEA & Quadrant \\
\hline Affin Islamic Bank Berhad & 1.487 & 0.63 & II \\
Al Rajhi Bank Berhad & 1.107 & 0.65 & II \\
Bank Bank Jabar Banten Syariah & 1.217 & 0.73 & II \\
Bank Central Asia Syariah & 1.064 & 0.62 & II \\
Bank Islam Brunei Darussalam & 1.052 & 0.78 & III \\
Bank Islamic Malaysia Berhad & 0.807 & 0.56 & IV \\
Bank Mega Syariah & 1.009 & 0.76 & III \\
Bank Muamalat Indonesia & 1.227 & 0.74 & I \\
Bank Muamalat Malaysia Berhad & 1.038 & 0.63 & IV \\
Bank Rakyat Indonesia Syariah & 0.744 & 0.76 & III \\
Bank Syariah Bukopin & 1.028 & 0.72 & IV \\
Bank Syariah Mandiri & 1.077 & 0.67 & II \\
Bank Victoria Syariah & 1.101 & 0.67 & II \\
CIMB Islamic Bank Berhad & 0.822 & 0.84 & III \\
\hline
\end{tabular}


Table 6.

ASEAN Islamic Banks Quadrant Category (Continued)

\begin{tabular}{lccc}
\hline DMU & MPI & DEA & Quadrant \\
\hline Hong Leong Islamic Bank Berhad & 1.212 & 0.73 & II \\
HSBC Amanah Berhad & 0.964 & 0.85 & III \\
Islamic Bank of Thailand & 1.148 & 0.78 & I \\
Kuwait Finance House Malaysia Berhad & 1.129 & 0.65 & II \\
Maybank Islamic Berhad & 0.69 & 0.95 & III \\
Maybank Syariah Indonesia & 1.011 & 0.61 & IV \\
OCBC Al-Amin & 1.056 & 0.75 & I \\
Panin Dubai Syariah & 1.409 & 0.81 & I \\
Public Islamic Berhad & 0.991 & 0.9 & III \\
RHB Islamic Bank Berhad & 0.899 & 0.83 & III \\
Mean & 1.054 & $\mathbf{0 . 7 3 5}$ & \\
\hline
\end{tabular}

Quadrant I includes banks that have MPI productivity scores and high DEA efficiency scores, so they can be considered as banks with very good performance. There are 4 banks that fall into this category, namely Bank Muamalat Indonesia, Islamic Bank of Thailand, OCBC Al-Amin and Panin Dubai Syariah.

Quadrant II includes banks that have a high MPI productivity score, but on the other hand have a low DEA efficiency score. The collection of banks in this group can be considered as banks with low "catching up" capabilities. The increase in the number of banks in the second quadrant is a sign of the ineffectiveness of banks in their efficiency performance. There are 8 banks included in this quadrant, namely Affin Islamic Bank Berhad, Al Rajhi Bank Berhad, Bank Jabar Banten Syariah Bank, Bank Central Asia Syariah, Mandiri Syariah Bank, Victoria Syariah Bank, Hong Leong Islamic Bank Berhad, and Kuwait Finance House. Malaysia Berhad.

Quadrant III includes a group of banks that have a low MPI productivity score, but on the other hand have a relatively high DEA efficiency score. Groups of banks in quadrant 3 can be considered as banks with low productivity performance, but able to achieve a relatively good increase in efficiency performance. There are 8 banks included in this quadrant, namely Islamic Bank Brunei Darussalam, Bank Mega Syariah, Bank Rakyat Indonesia Syariah, CIMB Islamic Bank Berhad, HSBC Amanah Berhad, Maybank Islamic Berhad, Public Islamic Berhad, and RHB Islamic Bank Berhad.

On the other hand, Quadrant IV is a group of banks with low MPI productivity scores and low DEA efficiency scores. The collection of banks in this group can be considered as banks whose performance level is relatively stagnant because of the small value of productivity and efficiency. There are 4 banks included in this quadrant, namely Bank Islamic Malaysia Berhad, Bank Muamalat Malaysia Berhad, Bank Syariah Bukopin, and Maybank Syariah Indonesia. 


\subsection{Analysis}

The period 2017-2018 was the most productive year in the Islamic banking sector of the four ASEAN countries, as reflected by their average productivity (TFPCH) of 1.657. Previous studies that have calculated the productivity of Islamic banks in ASEAN countries (for example, Rahim et al., 2013) show that beforehand, specifically from 2009 to 2013, the Islamic banking industry in Indonesia and Malaysia experienced inefficiencies, with the average efficiency rating not reaching $100 \%$ for the five consecutive years. Only later in 2017, it was found that the these banks had improved, in fact demonstrating better performance than conventional banks, and that each Islamic bank continued to make various efforts and develop programmes to increase the use of its inputs (Kamarudin et al., 2020).

When calculating and comparing the productivity level of each of the 24 banks, it was found that the bank with the highest level was Affin Islamic Bank Berhad, with a TFPCH value of 1.487 , an efficiency value of 1.000 , and a technology value of 1.487 , which means that many technological changes affect productivity compared to efficiency. In several previous studies, this bank has occupied a productive position with a TFPCH value above 1; to be exact, 1.022 in the 2012-2017 period (Rani et al., 2020). Likewise, compared to Islamic banking in the ASEAN and MENA regions (the Middle East and North Africa), Affin Islamic Bank is in the top 25 out of more than 60 banks (Rahim et al., 2013).

Interestingly, although the Islamic bank with the highest productivity value is Malaysian, namely Affin Islamic Bank Berhad, that with the lowest productivity value among the four ASEAN countries which are the object of the research is also Malaysian, namely Maybank Islamic Berhad, with a TFPCH value of 0.690, comprising values of change in efficiency or innovation (EFFCH) of 0.886 and in technology $(\mathrm{TECH})$ of 0.779. The data shows that Maybank Islamic Berhad has shortcomings in technology, indicated by its technology value, which is lower than the efficiency value. In the productivity research for the period 20122017, Maybank Islamic Berhad achieved a TFPCH value of 1.107, which means productive because of the value is more than one (Rani et al., 2020).

Based on the analysis results, several banks whose efficiency changes are relatively low including all Islamic banks in Indonesia, apart from Bank Muamalat Indonesia and Bank Rakyat Indonesia Syariah. One of the causes of the low change in efficiency is scale efficiency, which means the banks' inability to control output and costs.

In general, in the calculation per country, or the average of all Islamic banks in each of the four countries, the country that ranks first in the productivity order is Thailand, with one Islamic bank, namely the Islamic Bank of Thailand. The productivity value of Islamic bank in Thailand is 1.148, which indicates that it is productive, with a change in efficiency $(\mathrm{EFFCH})$ value of 1.075 and a technology $(\mathrm{TECH})$ value of 1.068. Islamic finance in Thailand has only recently developed, but it is currently one of ASEAN's largest economies (Solihin et al., 2016). Joint venture banking in Thailand for foreign investors is very limited, and the maximum percentage of ownership is only $37 \%$ (Wanke et al., 2017). Nevertheless, both Thailand and Brunei are represented by only one Islamic bank and hence their results may not be comparable to those for Indonesia and Malaysia.

When viewed on an annual basis, the productivity level of all ASEAN country Islamic banks continues to increase, with an average productivity value (TFPCH) 
of 1.038, and change in efficiency and innovation (EFFCH) value of 1.022, and technology change (TECH) value of 1.015 , which indicated productive.

It was also found that Malaysia, Brunei Darussalam and Thailand have higher values for efficiency changes than technological changes, but that Indonesia has a higher value for technological changes than efficiency changes. This shows that Indonesia's technology is better than in the other three countries.

As for the influential components, it was found that the efficiency and innovation factors were higher and more influential on the productivity of Islamic banking in ASEAN compared to technological change. Therefore, the challenge for all Islamic banks in ASEAN countries is to continue to improve the quality of their technology to increase productivity and realise higher productivity in the future.

Such technological improvement could be achieved by increasing digitalbased services, improving customer data security systems and implementing branchless banking. This will encourage the increased productivity of Islamic banks, meaning they can operate more efficiently.

\section{CONCLUSION AND RECOMMENDATIONS}

\subsection{Conclusion}

The study applied the BCC with VRS approach as a basic model in the DEA to measure the level of productivity of Islamic banks in ASEAN using the Malmquist index. The index was employed to assess the level of productivity of Islamic banks, both in terms of changes in efficiency and technology.

The results obtained from the Malmquist index scores (TFPCH) show that all 24 Islamic banks in the sample have experienced an increase in productivity, as seen by the TFPCH score of 1.038. The TFPCH value for efficiency changes (1.022) is higher than the value of technology changes (1.015). This means that the productivity of Islamic banks in ASEAN has been primarily influenced by increasing efficiency innovation.

The most productive bank is Affin Islamic Bank Berhad, with a TFPCH value of 1.487, and the bank with the lowest productive value is Maybank Islamic Berhad, with a TFPCH of 0.690 . The most productive country is Thailand, with a TFPCH value of 1.148. On the other hand, Malaysia is the least productive, with a TFPCH value of 1.017, while the period 2017-2018 was the most productive year, with a TFPCH value of 1.657 , which was perhaps sparked by Industry 4.0 .

\subsection{Recommendations}

Several recommendations related to the measurement of the level of efficiency and productivity of the ASEAN Islamic banking industry are given below.

The findings from the analysis of the productivity index are interesting to note. The increase in the productivity growth of Islamic commercial banks in ASEAN from 2010 to 2019 was mainly influenced by efficiency changes, as illustrated by the increased efficiency change (EFFCH) levels. However, changes in Islamic banking technology (TECH) in ASEAN countries are still lower than changes in efficiency, so it is necessary to continue to be improve this area through various innovations. 
Therefore, more innovative financial services are needed concerning the development of banking technology, such as infrastructure, including telephone banking, mobile banking, and internet banking, and financial technology (fintech). To date, contributors to banking productivity in ASEAN have not been from the technological aspect, but instead from managerial performance.

In addition, several factors can become obstacles to the development of the Islamic banking industry in Indonesia, namely: 1) inadequate capital; 2) weak understanding of Islamic banking by practitioners; 3) lack of government support; and 4) low trust and public interest in Islamic banks. Therefore, related parties need improvement in terms of capital, the quality of Islamic bank HR, and equally important, government support.

Recommendations for practitioners include the need to improve the quality of human resources in Islamic banks and the introduction of banking product innovations in order to provide more varied choices for customers. Increased efficiency changes and technical efficiency are both primary determinants of TFPCH. Recommendations for academics include the continued updating of information and data on the productivity of Islamic banking by adding other banks whose data are not yet available, or by expanding the research scope to other countries outside ASEAN or other regions, thus improving the limitations of the research. Islamic banks must be efficient and cost effective. In this way, they can compete with other financial institutions, including conventional banks. Technology can provide excellent service, allowing the market to grow. After technology is implemented, it is expected that the Islamic banking market share will experience growth.

Academicians can also update the research in terms of methodology, the data or research period, and by the determination of input-output variables that can be adjusted to a comprehensive description of the characteristics of Islamic banking, together with other determinant variables that are in line with the development of Islamic banking. Therefore, further research is expected to produce solutions to increase productivity, with various updates in accordance with the period in question.

The recommendation for regulators is that there is a need to improve Islamic banking quality from all aspects, especially efficiency. This has been attempted by the current Indonesian government to encourage mergers and to increase capital and expand the reach of financial inclusion. This merger effort will certainly require regulations to be developed and improved.

\section{REFERENCES}

Adarov, A. (2021). Dynamic interactions between financial cycles, business cycles and macroeconomic imbalances: A panel VAR analysis. International Review of Economics \& Finance, 74(July 2021), 434-451.

Andriyani, L., Usman, N., \& Pambuko, Z. B. (2020). Antecedents of social funds' productivity of Islamic Banks in Indonesia. Humanities and Social Sciences Reviews, 8(2), 488-494. https://doi.org/10.18510/hssr.2020.8256. 
Ascarya, A., \& Yumanita, D. (2008). Comparing the efficiency of Islamic banks in Malaysia and Indonesia. Bulletin of Monetary Economics and Banking, 11(2), 95119. https://doi.org/10.21098/bemp.v11i2.237.

Banker, R. D., Charnes, A., \& Cooper, W. W. (1984). Some models for estimating technical and scale inefficiencies in data envelopment analysis. Management Science, 30(9), 1078-1092.

Bjurek, H. (1996). The Malmquist total factor productivity index. The Scandinavian Journal of Economics, 98(2), 303-313.

Caves, D. W., Christensen, L. R., \& Diewert, W. E. (1982). The economic theory of index numbers and the measurement of input, output, and productivity. Econometrica: Journal of the Econometric Society, 50(6), 1393-1414.

Charnes, A., Cooper, W. W., \& Rhodes, E. (1978). Measuring the efficiency of decision-making units. European Journal of Operational Research, 2(6), 429-444.

Färe, R., Grosskopf, S., Lindgren, B., \& Roos, P. (1992). Productivity changes in Swedish pharmacies 1980-1989: A non-parametric Malmquist approach. Journal of Productivity Analysis, 3(1-2), 85-101.

Färe, R., Grosskopf, S., Norris, M., \& Zhang, Z. (1994). Productivity growth, technical progress, and efficiency change in industrialized countries. The American Economic Review, 84(1), 66-83.

GIFR (2019). Global Islamic Finance Report 2019.

Hadad, M. D., Hall, M. J. B., Kenjegaliev, K. A., Santoso, W., \& Simper, R. (2011). Productivity changes and risk management in Indonesian banking: A Malmquist analysis. Applied Financial Economics, 21(12), 847-861. https://doi.or $\mathrm{g} / 10.1080 / 09603107.2010 .537636$.

Johnes, J., Izzeldin, M., Pappas, V., \& Alexakis, C. (2019). Performance and productivity in Islamic and conventional banks: Evidence from the global financial crisis. Economic Modelling, 79, 1-14. https://doi.org/10.1016/j. econmod.2018.09.030.

Jubilee, R. V. W., Kamarudin, F., Latiff, A. R. A., Hussain, H. I., \& Tan, K. M. (2021). Do Islamic versus conventional banks progress or regress in productivity level?. Future Business Journal, 7(1), 1-22.

Kamarudin, F., Hue, C. Z., Sufian, F., \& Mohamad Anwar, N. A. (2017). Does productivity of Islamic banks endure progress or regress? Empirical evidence using data envelopment analysis based Malmquist Productivity Index. Humanomics, 33(1), 84-118. https://doi.org/10.1108/H-08-2016-0059.

Kamarudin, F., Mohamad Anwar, N. A., Md. Nassir, A., Sufian, F., Tan, K. M., \& Iqbal Hussain, H. (2020). Does country governance and bank productivity Nexus matters? Journal of Islamic Marketing (ahead-of-print). https://doi. org/10.1108/JIMA-05-2019-0109.

Kim, D. (2021). Economies of scale and international business cycles. Journal of International Economics, 131(July 2021), 103459.

Kumar, S. (2008). An analysis of efficiency-profitability relationship in Indian public sector banks. Global Business Review, 9(1), 115-129.

Nugrohowati, R. N. I., Fakhrunnas, F., \& Haron, R. (2020). Examining technological and productivity change in the islamic banking industry. Pertanika Journal of Social Sciences and Humanities, 28(4), 3355-3374. https://doi.org/10.47836/ pjssh.28.4.47. 
Omar, M. A., Abd. Majid, M. S., \& Rulindo, R. (2007). Efficiency and productivity performance of the national private banks in Indonesia. Gadjah Mada International Journal of Business, 9(1), 1-18.

Otaviya, S. A., \& Rani, L. N. (2020). Productivity and determinant of Islamic banks evidence from Indonesia. Journal of Islamic Monetary Economics and Finance, 6(1), 189-212. https://doi.org/10.21098/jimf.v6i1.1146.

Ozcan, Y. (2008). Health care benchmarking and performance evaluation: An assessment using data envelopment analysis. Boston: Springer.

Rahim, A., Rahman, A., \& Rosman, R. (2013). Efficiency of Islamic banks: A comparative analysis of MENA and Asian countries. Journal of Economic Cooperation and Development, 34(1), 63-92.

Rani, L. N., Sukmaningrum, P. S., \& Salleh, M. C. M. (2020). A comparative analysis of the productivity of Islamic banking in Indonesia, Malaysia and Brunei Darussalam during the period 2012-2017. International Journal of Innovation, Creativity and Change, 11(11), 470-491.

Refinitiv, \& Islamic Corporation for the Development of the Private Sector. (2020). Islamic Finance Development Report 2020.

Rusydiana, A. S., \& Marlina, L. (2019). Financial and social efficiency on Indonesian Islamic banks. Journal of Islamic Monetary Economics and Finance, 5(3), 579-602.

Sharma, D., Sharma, A. K., \& Barua, M. K. (2013). Efficiency and productivity of banking sector: A critical analysis of literature and design of conceptual model. Qualitative Research in Financial Markets, 5(2), 1755-4179.

Solihin, S., Achsani, N. A., \& Saptono, I. T. (2016). The Islamic banking and the economic integration in ASEAN. Bulletin of Monetary Economics and Banking, 19(1), 81-106. https://doi.org/10.21098/bemp.v19i1.601.

Sufian, F. (2007). Malmquist Indices of productivity change in Malaysian Islamic banking industry: Foreign versus domestic banks. Journal of Economic Cooperation, 28(1), 115-150. https://doi.org/10.1007/BF02294970.

Sufian, F. (2010). Productivity, technology and efficiency of de Novo Islamic banks: Empirical evidence from Malaysia. Journal of Financial Services Marketing, 15(3), 241-258. https://doi.org/10.1057/fsm.2010.20.

Usman, N., Andriyani, L., \& Pambuko, Z. B. (2019). Productivity of Islamic banks in Indonesia: Social funds versus financial funds. Journal of Asian Finance, Economics and Business, 6(3), 115-122.

Wanke, P., Hassan, M. K., \& Gavião, L. O. (2017). Islamic banking and performance in the ASEAN banking industry: A topsis approach with probabilistic weights. International Journal of Business and Society, 18(S1), 129-150.

Yan, C., \& Huang, K. X. D. (2020). Financial cycle and business cycle: An empirical analysis based on the data from the U.S. Economic Modelling, 93(December 2020), 693-701. https://doi.org/10.1016/j.econmod.2020.01.018.

Yulita, I., \& Rizal, S. (2016). Islamic banking efficiency: Comparative studies between Malaysia and Indonesia. Signifikan: Jurnal Ilmu Ekonomi, 5(1), 31-50. https://doi.org/10.15408/sjie.v5i1.3129. 
This page is intentionally left blank 